\title{
BEARING CAPACITY AND STABILITY OF ELASTICALLY FIXED CFT SLENDER COLUMNS
}

\author{
Marija Lazovic, Janko Radovanovic, Biljana Deretic Stojanovic
}

Professional paper

CFT columns are one of the basic structural elements in "top-down" construction method. Because of the large depth of excavation the question of stability of these columns raises. This paper presents a procedure for calculation of critical buckling force of CFT columns which are on the upper side elastically fixed in the concrete ceiling and on the bottom side elastically fixed in the drilled pile. Using computer programs ABAQUS 6.12 and LPILE, as well as appropriate constitutive models the boundary conditions on the upper and lower end of the CFT columns are determined. For a building called "Cvijetni prolaz" in Zagreb, using program created in Excel the critical buckling force of elastically fixed CFT columns is determined. The dependence of the critical buckling force decreasing with increasing depth of excavation is presented. The impact of concrete class, diameter and wall thickness of the steel section, length and diameter of the pile, the thickness of the ceiling on the critical buckling force of CFT columns is analysed. The results are shown in diagrams and tables.

Keywords: CFT column; FEM; p-y curve; stability of bifurcation

Nosivost i stabilnost elastično uklještenih CFT vitkih stupova

Stručni članak

CFT stupovi su jedan od osnovnih konstrukcijskih elemenata u "top-down" metodi gradnje ("odozgor prema dolje"). Kako su dubine iskopa velike postavlje se pitanje stabilnosti ovih stupova. U radu je dan prijedlog postupka proračuna kritične sile izvijanja CFT stupa koji je s gornje strane elastično uklješten u izvedeni strop, a s donje strane elastično uklješten u bušeni pilon. Primjenom programa LPILE i ABAQUS 06.12, kao i odgovarajućih konstitutivnih modela određeni su granični uvjeti na gornjem, odnosno donjem kraju CFT stupa. Za objekt Cvjetni prolaz u Zagrebu primjenom programa modeliranog u Excell-u izračunata je kritična sila izvijanja obostrano elastično uklještenog CFT stupa. Prikazana je ovisnost opadanja kritične sile izvijanja s porastom dubine iskopa. Analiziran je utjecaj klase betona, promjera i debljine zida čeličnog profila, dužina i promjer šipa, debljina stropa na vrijednost kritične sile izvijanja CFT stupa. Dobiveni rezultati prikazani su u dijagramima i tablicama.

Ključne riječi: CFT stupovi; bifurkaciona stabilnost; MKE; p-y krivulje

\section{Introduction}

CFT columns are composite columns with rectangular or circular hollow steel sections filled with concrete. Due to its structural advantages they have found wide application in engineering practice, particularly in seismic areas. Comparing to the columns made only of steel or concrete they provide greater capacity, rigidity and ductility. Concrete infill increases resistance to the fire action and fully or substantially prevents buckling of steel profile and contributes to the stability of the entire column. Steel profile takes over the function of the longitudinal and transverse reinforcement. CFT columns use steel section as permanent formwork, which provides easier and faster construction compared to conventional concrete columns. These composite columns can be produced as prefabricated elements, which then speed up construction time. Also, using the CTF columns more free space is obtained, because they have smaller cross sections compared with plain concrete columns.

CFT columns represent one of the basic structural elements in top down construction method. In this method the construction works are carried out simultaneously in underground and above ground part of the object. Given that this is the deep excavation, it is necessary to calculate not only the capacity but also the stability of the CFT columns. A very small number of works have been written on this issue. Authors Yasser Khodair and Ahmed Abdel Mohta analysed the interaction between structure and pile using the differential method and program LPILE, as well as finite element method with programs ABAQUS and SAP2000 [1]. Authors P. Senthil Kumar, K. Babu Karuppaiahand P. Parameswaran examined stability of partially buried reinforced concrete piles with eccentric load in sand [2]. Authors M. Lazovic, B. Deretic Stojanovic and J. Radovanovic present the general principles for calculation of elastically fixed CFT columns [3].

In MS Excel, using FEM, a program for determining the critical buckling force of CFT columns which are on the upper side elastically fixed in concrete ceiling and on the bottom side in the drilled pile was created. Boundary conditions are defined with nodal stiffness matrix at the ends of the column. With computer programs ABAQUS [4] and LPILE [5] matrix of flexibility is determined, whose inversion gives the stiffness matrix for the upper and lower end of the column.

By applying the above program the critical buckling force of elastically fixed CFT column for building "Cvijetni prolaz" in Zagreb was calculated. Also, the influence of the class of concrete, diameter and wall thickness of the steel section, length and diameter of the pile and the thickness of the ceiling on the critical buckling force of CFT columns is analysed.

\section{Application of CFT columns in "top-down" method of construction}

When performing deep excavations, in order to ensure the stability of the sides of the excavation, there is a need for creating a protective structure of the foundation pit. For greater depth shoring of pits can be made in several levels. Such works are complex, relatively expensive and time consuming. Therefore, in recent time there is a tendency to perform pit shoring with the construction of the underground part of the building, and at the same time the underground part of the object is being built. One way of performing these works is the so- 
called "top-down" construction. Economic analyses show that these solutions are considerably more favourable than other methods where shoring of foundation pit is performed with temporary structures or with geotechnical anchors. Proposed method of works considerably shortens the time needed for the completion of works. This is especially important when the works are carried out in urban conditions and when they prevent normal functioning of traffic. One of the important structural elements in this method is the interior ceiling supports. These elements are usually performed in places of future columns as temporary supports and are concreted to final dimensions later on. From the surface level, or from the level -1 , bored piles are performed and in them steel members as temporary supports are set. The piles are concreted to the elevation of the bottom of the future foundation slab, and up the temporary supports are usually performed as a steel pipe filled with concrete i.e. CFT columns. Furthermore, the excavation is carried out for the height of two floors and ceilings of the underground part of the object are performed successively with excavation.

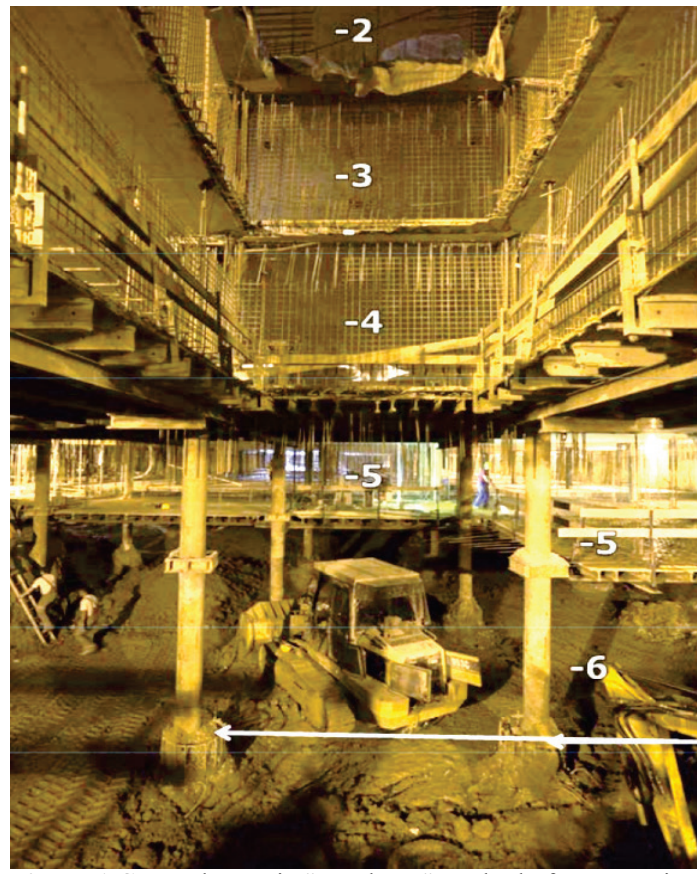

Figure 1 CFT columns in "top-down" method of construction

Regarding the capacity of CFT columns the critical moment occurs when the excavation reaches the final depth. At that time the temporary column has the largest load from the structure of the above part of building, and the buckling length of the column is the biggest. Usually this length is through two floors plus the thickness of the foundation slab, the buffer layer and the drainage layer, which in concrete terms ranges from 7 to $900 \mathrm{~m}$. Given the small cross sectional dimensions of the temporary supports and a great load, the question of its capacity rises, taking into account the capacity of the materials used for the construction, and the possibility of buckling of these elements. Fig. 1 presents the interior of the foundation pit of one office building in Zagreb, which has 6 underground floors. In the presented phase of works 6 above ground floors of the structure were already built.
Temporary supports are made of steel pipes $\varnothing 355 \mathrm{~mm}$ that are filled with concrete. These pipes are elastically fixed in bored piles $\varnothing 1200 \mathrm{~mm}$, whose depths are 8,00 to $10,00 \mathrm{~m}$ below the level of the excavation.

This paper presents a method for calculation of critical buckling force of temporary supports which are on the upper side elastically fixed in the ceiling of the structure, and on the bottom in a drilled pile. This problem was solved by FEM, while the nodal stiffness matrix of the pile top is determined using a method of equivalent frame and $p-y$ curves for the soil.

\section{Determination of critical load \\ 3.1 Creating stiffness matrix for the system of finite elements}

In this section, we will examine the problem of bifurcational stability in which the determination of the critical load is reduced to the problem of determining the eigenvalues of the system. Minimal eigenvalue determines the level of load at which the system is stable. At the bifurcation point the system is in indifferent equilibrium. In the state of indifferent equilibrium the second variation of the potential energy of the system is equal to zero. Critical load can be determined using a matrix analysis from the condition that the double variation of expression for the potential energy of the system by movement is equal to zero [6]:

$\delta^{2} \Pi=\delta \boldsymbol{q}^{\mathrm{T}} \cdot\left(\boldsymbol{K}_{0}+\boldsymbol{K}_{g}\right) \cdot \delta \boldsymbol{q}=0$

respectively

$\left|\boldsymbol{K}_{0}+\lambda \cdot \boldsymbol{K}_{g}\right|=0$.

$\boldsymbol{K}_{0}$ and $\boldsymbol{K}_{g}$ are the stiffness matrix of the finite element pole according to the linear theory of bending and the geometric stiffness matrix, $\boldsymbol{q}$ - vector of displacements at nodes of the element, while $\lambda$ represents the proportionality factor that can be calculated as follows:

$\lambda=\frac{S}{30} \cdot \frac{l^{2}}{E I}$

where are: $S$ - axial force; $l$ - length of the finite element.

It is necessary to determine the characteristic minimum value $\lambda$ min that can be used to calculate critical load and which defines the first tone of buckling.

After the formation of the stiffness matrix for the finite element according to bending theory and geometric stiffness matrix for the finite element, with overlapping of these matrices in mutual nodes the stiffness matrix of the system of finite elements is created. Discretization of the column is made with a number of finite elements. The cross section and the axial force do not change in length of the column, so the division into finite elements of the same length can be adopted. In the numerical example column is divided into six finite elements, so that the total number of members of the stiffness matrix of the system of finite elements is $14 \times 14$. 


\subsection{Determining boundary conditions at the upper end of the CFT column}

To determine the critical buckling force of the column, it is necessary to enter the boundary conditions at the ends of the column. Boundary conditions are defined with nodal stiffness matrix at the ends of the column, which are added to the system stiffness matrix of finite elements. On the upper side the column is fixed on floor ceiling and column on a higher floor. For practical calculations it is sufficient to consider only part of the column above the floor and the ceiling above the column which is analysed. Nodal stiffness matrix at the top of the column can be obtained by inversion of flexibility matrix. Elements of flexibility matrix are obtained by calculating displacements due to unit forces in the node. Since the ceilings are relatively rigid in their planes, deformation in the horizontal direction is ignored, which is equivalent with fixed support in the horizontal direction. In this way, the nodal matrix is reduced to a number which defines the stiffness at rotation. For the purposes of determining the displacement of the node at the upper end of the CFT column due to the unit force a computer program ABAQUS 6.12 is applied. Finite elements C3D8R and S4R elements are applied for modelling the ceiling and part of the column above, respectively [4]. On the accuracy of the obtained results a significant effect has the adopted constitutive model for concrete. In this paper Concrete Damaged Plasticity model was applied, where the angle of dilatation had a value of $20^{\circ}$ [7]. Poisson ratio was 0,2 . The relationship between stress and dilatation is shown in Fig. 2 [7].

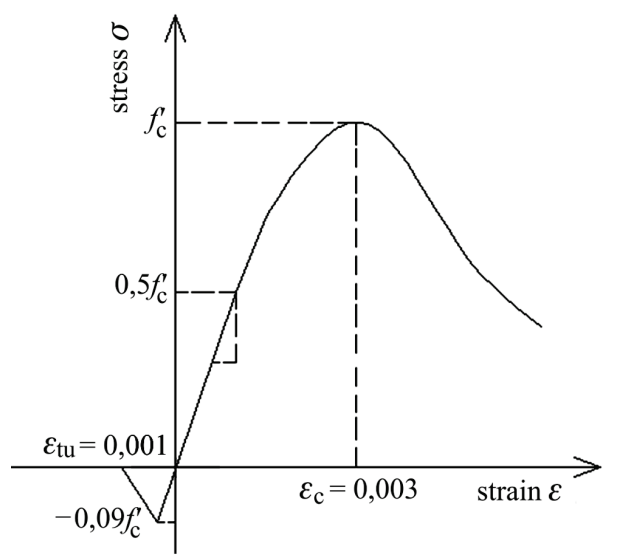

Figure 2 Diagram of stress-dilatation of concrete

Dilatation $\varepsilon_{c}^{\prime}$ which corresponds to the strength of concrete on pressure $f_{c}^{\prime}$ is adopted as 0,003 . Linear behaviour is adopted until the value of $0,5 f^{\prime}$, while the modulus of elasticity of concrete is defined as [8]:

$$
E_{\mathrm{c}}=9500 \cdot \sqrt{f_{c}^{\prime}+8} \mathrm{MPa}
$$

Relationship $\sigma-\varepsilon$ for compressed concrete can be expressed with the fallowing equation [9]:

$$
f=\frac{E_{\mathrm{c}} \cdot \varepsilon_{\mathrm{c}}}{1+\left(R+R_{\mathrm{E}}-2\right) \cdot\left(\frac{\varepsilon}{\varepsilon_{\mathrm{c}}^{\prime}}\right)-(2 R-1) \cdot\left(\frac{\varepsilon}{\varepsilon_{\mathrm{c}}^{\prime}}\right)^{2}+R \cdot\left(\frac{\varepsilon}{{\varepsilon_{\mathrm{c}}^{\prime}}^{\prime}}\right)^{3}}
$$

where the coefficients $R_{\mathrm{E}}$ and $R$ are calculated according to the following expressions:

$$
\begin{aligned}
& R_{\mathrm{E}}=\frac{E_{\mathrm{c}} \cdot \varepsilon}{f^{\prime}{ }_{\mathrm{c}}}, \\
& R=\frac{R_{\mathrm{E}} \cdot\left(R_{\sigma}-1\right)}{\left(R_{\sigma}-1\right)^{2}}-\frac{1}{R_{\varepsilon}},
\end{aligned}
$$

while $R_{\sigma}$ and $R_{\varepsilon}$ are equal to 4 .

Concrete tensile strength $f_{\mathrm{t}}$ amounts of approximately $9 \%$ of strength of concrete in compression $f_{\mathrm{c}}^{\prime}$. After reaching the strength of concrete on pressure the material will weaken. Tensile stress reaches a value of zero at dilatation of 0,001

Fig. 3 presents a model of the ceiling and part of column to a higher floor. The model is divided in 729 finite elements. Connection between ceiling and column is modelled using surface based shell to solid coupling.

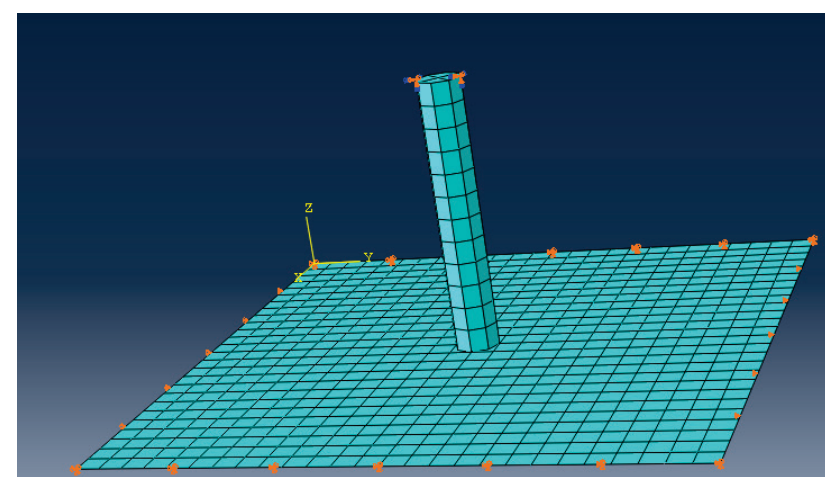

Figure 3 Model of the ceiling and part of the column to a higher floor

\subsection{Determining boundary conditions at the lower end of the CFT column}

One of the methods for calculation in problems of soil structure interaction which is often applied is the equivalent frame method $[10,11]$. In this method, a protective structure is treated as a beam which is supported by a system of elastic springs which simulate the effect of the soil. If we ignore out diagonal elements in the soil flexibility matrix the flexibility matrix is reduced to a diagonal matrix. In this way, soil behaviour is described with Winkler's model. Accuracy of the results which are obtained largely depends on the modelling of soil behaviour and the proper modelling of the system in different phases of construction. Soil properties largely depend on the geological history. They can vary considerably and therefore they should be measured. In recent years there has been significant progress in the constitutive modelling of soil behaviour. The main objectives of the constitutive model of the soil are that they well describe the behaviour of the soil and that the parameters for their description can be obtained on the basis of conventional experiments, as well as that their application in numerical analysis is not complicated.

Using $p-y$ curves relationships between the size of the horizontal loads (soil reaction) and the values of horizontal displacements are established. This method has many advantages: a relationship $\sigma-\varepsilon$ for the pile is nonlinear, time of calculation decreases, behaviour of the 
surrounding soil for a pile loaded by static or dynamic loading can be modelled, pile may have a variable cross section in depth, capacity of the pile can be calculated for a pile passing through several layers of different mechanical properties. However, the application of $p-y$ curves has certain drawbacks: the soil is not treated as a continuum, but as a system of elastic springs, establishing relationships of $p-y$ curves for each layer of penetration is expensive and difficult, and the interpolation of curves is not possible.

Complex three dimensional problems are reduced to one dimensional in which the soil is replaced with concentrated springs with appropriate stiffness. The shape of these curves depends on the characteristics of the soil and type of load, so that they are specifically defined for a coherent soil, and for non-coherent soil. Also, $p-y$ curves are greatly influenced with the way on which the pile is loaded, the diameter of the pile, the level of groundwater, the level of consolidation of soil, erosion of soil, way of creating a pile, soil compaction, swelling and compressibility of the soil. The parameters that define these curves are usually determined experimentally.

To describe the nonlinear behaviour of the soil in this paper a modified $p-y$ curve which was originally proposed by scientists Reese and Welch was used [10]. Soil reaction in nonlinear field is well described with the original equation:

$$
\frac{p}{p_{\mathrm{ul}}}=0,5 \cdot\left(\frac{y}{y_{50}}\right)^{\frac{1}{4}} .
$$

However, it was observed that the soil is behaving too stiff for the load in the linear region, due to the low number of parameters which are used to form the equation of the curve. This problem was overcome by introducing a new parameter indicated by the initial stiffness marked with $k$, which represents the slope of the tangent on the curve in the first part of the diagram. Fig. 4 presents the modified $p-y$ curve, where are: pul- ultimate soil resistance per unit length, $y_{50}$ - horizontal ground motion at $0,5 p_{\mathrm{ul}}$.

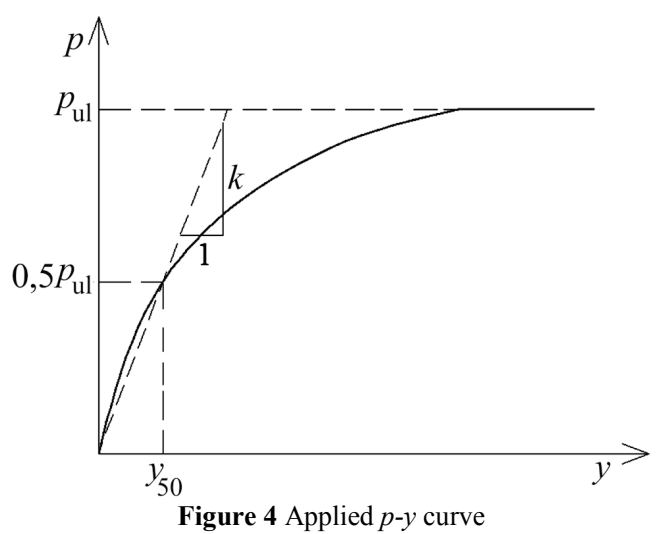

In this paper it is suggested that the displacements of the pile are calculated with secant values of spring stiffness. With modified $p-y$ curve, it is proposed that its rigidity is determined for the load of $0,5 p$ ul and movement of $y_{50}$. In this way, the problem becomes linear, and the elements of the flexibility matrix of the pile top can be calculated in a single step by calculation of the influences in the equivalent frame. With inversion of flexibility matrix the stiffness matrix at the lower end of CFT column is obtained. This matrix is simply added to the stiffness matrix of the finite elements of column and finally the system of equations to determine the critical force in the CFT column is formed. The problem is reduced to the determination of the size of the axial force, which leads to the fact that the value of the determinant of the system is equal to zero. For the purpose of solving this problem a program was made in MS Excel, which, using an iterative process, rapidly determines the critical buckling force of the column, which represents the lowest eigenvalue in the observed system of equations.

\section{Calculation of critical buckling force for a building called "Cvijetni prolaz" in Zagreb}

For a building of "HOTO" group from Zagreb as temporary supports in "top-down" construction method CFT columns were applied. The diameter of the pipe was $\varnothing 355 \mathrm{~mm}$, wall thickness $t=25 \mathrm{~mm}$ and steel class S355, filled with concrete class $\mathrm{C} 25 / 30$ which are embedded in the bored piles with a diameter $\varnothing 1200 \mathrm{~mm}$, length $l=$ $8,00 \mathrm{~m}$ and concrete class $\mathrm{C} 25 / 30$. The elasticity modulus of steel pipes is $210 \mathrm{GPa}$, while the elasticity modulus of concrete core is $30,5 \mathrm{GPa}$. With the proposed procedure the critical buckling force of CFT columns length of 7,00 $\mathrm{m}$ is determined. Design value of effective flexural stiffness $(E I)_{\text {eff, II }}$ for the cross section of the composite column is calculated with the following expression [12]:

$$
(E I)_{\mathrm{eff}, \mathrm{II}}=K_{0} \cdot\left(E_{\mathrm{a}} I_{\mathrm{a}}+K_{\mathrm{e}, \mathrm{II}} E_{\mathrm{cm}} I_{\mathrm{c}}\right)=73305,18 \mathrm{kN} \cdot \mathrm{m}^{2}
$$

where are: $K_{\mathrm{e}, \text { II }}$ - a correction coefficient, which should be taken as 0,$5 ; K_{0}$ - calibration coefficient which should be taken as 0,$9 ; E_{\mathrm{a}}, E_{\mathrm{cm}}$ - modulus of elasticity of steel and concrete; $I_{\mathrm{a}}, I_{\mathrm{c}}$ - moments of inertia of steel section and the concrete section without cracks in the plane of bending which is under consideration.

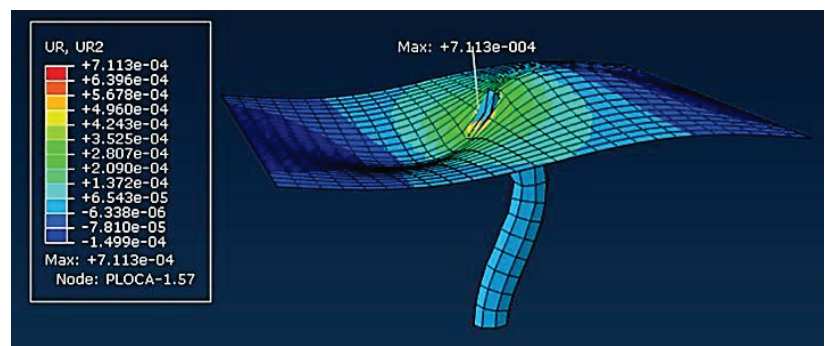

Figure 5 Displacement due to unit force on the upper end of the CFT column

By applying computer programs ABAQUS and LPILE the boundary conditions on the upper and lower end of the CFT column are calculated, respectively. Fig. 5 presents the displacement of the top of the column due to the bending moment with intensity of $100 \mathrm{kN} \cdot \mathrm{m}$. The span between columns is $\lambda=6,50 \mathrm{~m}$, the diameter of the column above the analysed CFT column is $50 \mathrm{~cm}$, the thickness of the ceiling is $20 \mathrm{~cm}$ and the concrete class applied for the described construction elements is $\mathrm{C} 25 / 30$. 
The computer program LPILE obtained values of horizontal displacement and rotation of the pile top, with diameter $\varnothing 1200 \mathrm{~mm}$ and length of $8,00 \mathrm{~m}$ due to unit forces shown in Fig. 6 . The following characteristics of the soil obtained from geomechanic studies were used [13]: effective volume weight of soil $\gamma^{\prime}$, undrained cohesion $c_{\mathrm{u}}$, coefficient $k$ and the characteristic dilatation corresponding to undrained cohesion $\varepsilon_{50}=0,01[10]$.

Fig. 6 loading case 1 represents the displacement of the pile due to horizontal forces of $100 \mathrm{kN}$, while loading case 2 presents a displacement of the pile due to bending moment with intensity of $100 \mathrm{kN} \cdot \mathrm{m}$.

With inversion of flexibility matrix nodal stiffness matrix for upper and lower end of the CFT column is obtained.

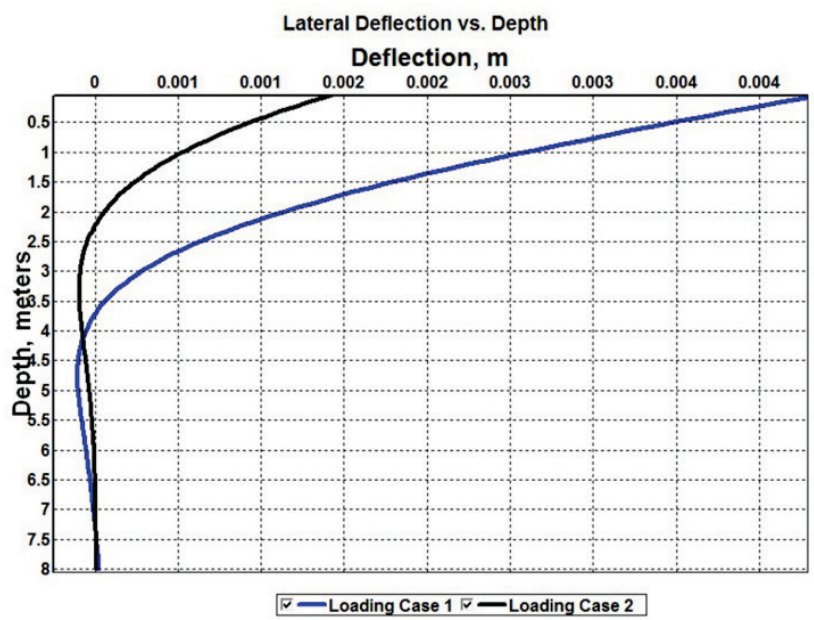

Figure 6 Displacement due to unit force on the lower end of the CFT column

With application of a program created in MS Excel, the following results were obtained: $P_{\mathrm{cr}}$ - critical buckling force for CFT column elastically fixed at both ends, $P_{\mathrm{cr}, \mathrm{sl}}$ - critical buckling force for CFT column simply supported at both ends, $P_{\text {cr,uk }}$ - critical buckling force for CFT column fixed at both ends, $\mu$ - buckling length coefficient, $l_{0}$ - free buckling length of CFT column.

\begin{tabular}{|r|c|l|}
\hline$\lambda=$ & 3,497 & \\
\hline & & \\
\hline Pcr $=$ & 51633,78 & $\mathrm{kN}$ \\
\hline & & \\
\hline Pcr,sl $=$ & 14765,16 & $\mathrm{kN}$ \\
\hline & & \\
\hline Pcr,uk= $=$ & 59060,65 & $\mathrm{kN}$ \\
\hline & & \\
\hline $\mathbf{l}=$ & 7,00 & $\mathrm{~m}$ \\
\hline$\mu=$ & 0,534 & \\
\hline & & \\
\hline $10=$ & 3,743 & $\mathrm{~m}$ \\
\hline
\end{tabular}

Figure 7 Results of calculation of critical buckling force of the CFT column

Based on these results it can be concluded that the results obtained are closer to the critical buckling force for CFT column fixed at both ends.

Fig. 8 presents the change in the critical buckling force of CFT column with an increase in depth of excavation, if the length of the CFT column ranges from $7,00 \mathrm{~m}$ to $9,00 \mathrm{~m}$ which roughly corresponds to two story heights, depending on the thickness of the foundation slab. With the increase in the length of the column from $7,00 \mathrm{~m}$ to $9,00 \mathrm{~m}$ critical buckling force has declined $510633,78 / 32610,78=1,58$ times

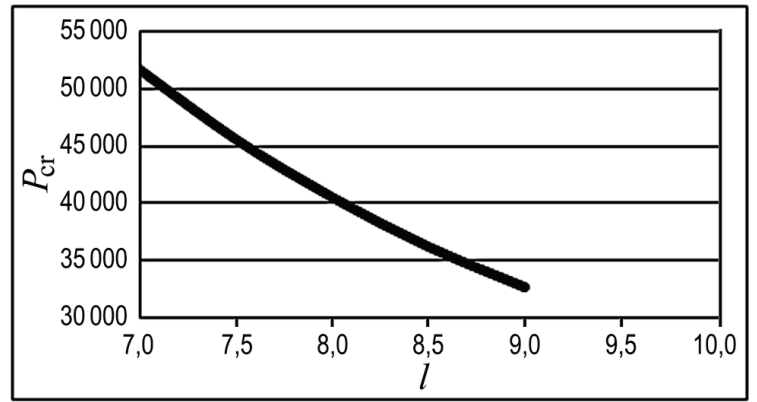

Figure 8 Change in the critical buckling force of the CFT column elastically fixed on both sides depending on the column length

\section{$5 \quad$ Parametric analysis}

The impact of the concrete class, diameter and wall thickness of the steel section, length and diameter of the pile, the thickness of the ceiling on the critical buckling force of the CFT column was analysed. The results are shown in the diagrams.

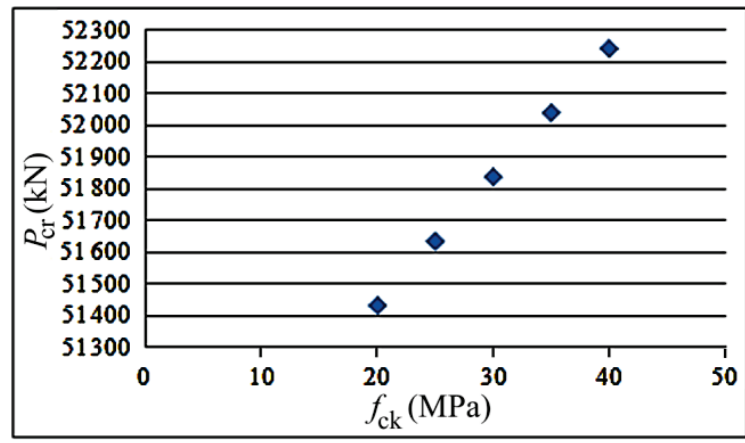

Figure 9 Change in the critical buckling force of the CFT colum elastically fixed on both sides depending on the concrete class

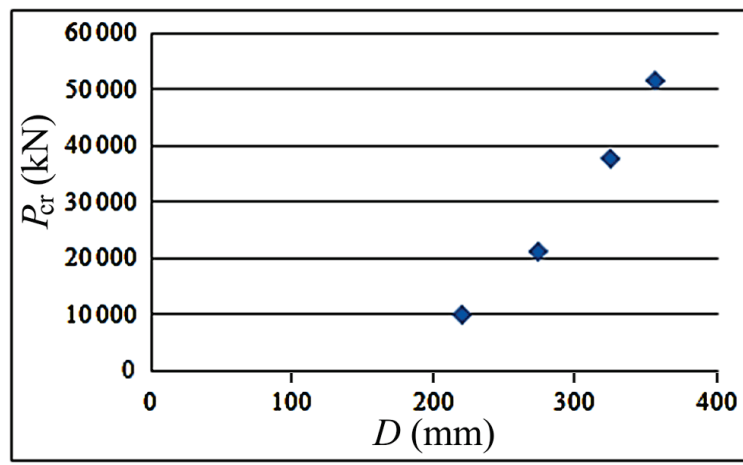

Figure 10 Change in the critical buckling force of the CFT column elastically fixed on both sides depending on the steel pipe diameter

Based on the obtained results it can be concluded that the critical buckling force of the CFT column elastically fixed on both sides rises almost linearly with a rise in concrete class.

Fig. 10 presents the dependence of the critical buckling force of the CFT column elastically fixed on both sides depending on the diameter of steel section, with the following diameters of steel profiles that are 
commonly used in practice: $219,1 \mathrm{~mm}, 273,0 \mathrm{~mm}, 323,9$ $\mathrm{mm}, 355,6 \mathrm{~mm}$. Adopted class of concrete is $\mathrm{C} 25 / 30$.

It can be concluded that the critical buckling force of the CFT column depends greatly on the diameter of the steel section. With increasing of diameter of the steel pipe from $219,1 \mathrm{~mm}$ to $355,6 \mathrm{~mm}$ critical force has increased $51633,78 / 10103,92=5,11$ times.

Fig. 11 presents the dependence of the critical buckling force of the CFT column elastically fixed on both sides depending on the thickness of the steel section, with the following thickness of steel profiles that are commonly used in practice: $8 \mathrm{~mm}, 10 \mathrm{~mm}, 12,5 \mathrm{~mm}, 16$ $\mathrm{mm}, 17,5 \mathrm{~mm}, 20 \mathrm{~mm}$ and $25 \mathrm{~mm}$.

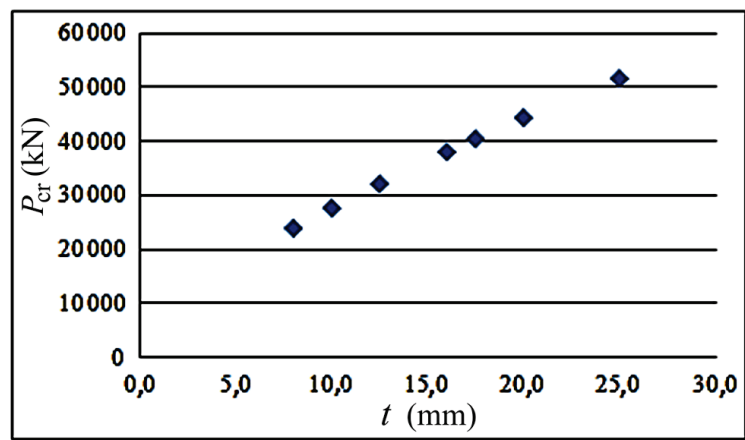

Figure 11 Change in the critical buckling force of the CFT column elastically fixed on both sides depending on the steel pipe thickness

The change is approximately linear, if there are small changes in wall thickness. With the increase in wall thickness from $8 \mathrm{~mm}$ to $12,5 \mathrm{~mm}$ relative change of the critical buckling force is $34,37 \%$, while with the increase in wall thickness from $16 \mathrm{~mm}$ to $20 \mathrm{~mm}$ relative change of the critical buckling force is $16,65 \%$. Based on this, it can be concluded that the relative change of the critical buckling force of CFT column is higher, if the wall thickness of the steel profile is smaller.

Table 1 Change in the critical buckling force of the CFT column elastically fixed on both sides depending on the length and diameter of the pile and thickness of the ceiling

\begin{tabular}{|c|c|c|c|c|c|}
\hline$L / \mathrm{m}$ & $D / \mathrm{mm}$ & $d / \mathrm{mm}$ & $P_{\mathrm{cr}} / \mathrm{kN}$ & $P_{\mathrm{cr}} / P_{\mathrm{cr}, \mathrm{sl}}$ & $P_{\mathrm{cr}} / P_{\mathrm{cr}, \mathrm{uk}}$ \\
\hline 8,00 & 600 & 200 & 50622,34 & 3,428 & 0,857 \\
\hline 8,00 & 800 & 200 & 51094,85 & 3,460 & 0,865 \\
\hline 8,00 & 1200 & 200 & 51633,78 & 3,497 & 0,874 \\
\hline 8,00 & 1200 & 250 & 53833,79 & 3,646 & 0,912 \\
\hline 8,00 & 1200 & 300 & 55655,81 & 3,769 & 0,942 \\
\hline 9,00 & 1200 & 200 & 51633,78 & 3,497 & 0,874 \\
\hline 10,00 & 1200 & 200 & 51633,78 & 3,497 & 0,874 \\
\hline
\end{tabular}

If the length and diameter of the pile, or the thickness of the ceiling changes, the boundary conditions are also changed. In this case, it is necessary to calculate the new generalized displacements, that is, determine the flexibility matrix whose inversion gives the stiffness matrix of the upper and lower end of the CFT column. Tab. 1 presents the dependence, where are: $d$ - thickness of the ceiling, $D$ - pile diameter, $L$ - length of the pile.

\section{Conclusion}

Based on the presented work the following conclusions can be drawn:
1) "Top-down" construction method has a number of advantages over other methods of building the underground part of the object and pit protection. When designing CFT columns-temporary supports, as one of the basic structural elements in this method of construction, it is necessary to take care of the stability of these columns. This is especially important when the depth of the excavation reaches the highest value and when the base plate is not yet constructed.

2) With the proposed iterative procedure it is possible to determine the size of the elastic critical buckling force of the CFT column, taking into account the boundary conditions at the ends.

3) With the application of computer program ABAQUS and the appropriate constitutive model for concrete it is possible to determine the flexibility matrix of the upper end of the CFT column, whose inversion gives the stiffness matrix that defines the boundary conditions at the upper end of the column.

4) $p-y$ curves are suitable to describe the behaviour of the soil around the pile. With their use elements of the stiffness matrix for the pile top, which define the boundary conditions at the lower end of the CFT column, can be calculated.

5) The critical buckling force is significantly affected by the depth of the excavation, or length of the CFT column. With the increase in concrete class critical buckling force increases approximately linearly. Also, the value of $P_{\mathrm{cr}}$ is greatly influenced by the diameter and the thickness of the steel section. With increasing diameter of the steel profile from 219,1 $\mathrm{mm}$ to $355,6 \mathrm{~mm}$ critical force has increased more than 5 times, while with the increase in wall thickness from $8 \mathrm{~mm}$ to $25 \mathrm{~mm} P_{\text {cr }}$ has increased more than 2 times.

6) Based on the obtained results it can be concluded that the boundary conditions on both sides of CFT column are closer to fixed support comparing to free support. This phenomenon is especially visible if the thickness of the ceiling and the diameter of the pile are higher, while the length of the pile does not have a significant impact on the boundary conditions of the CFT column.

\section{Acknowledgements}

The first author thanks the Ministry of Science and Technology of the Republic of Serbia for the financial support through the project III 42012.

\section{References}

[1] Khodair, Y.; Abdel-Mohti, A. Numerical Analysis of PileSoil Interaction under Axial and Lateral Loads. // International Journal of Concrete Structures and Materials. 8, 3(2014), pp. 239-249. DOI: 10.1007/s40069-014-0075-2

[2] Senthil Kumar, P; Babu Karuppaiah, P.; Parameswaran, P. Buckling Behavior of Partially Embedded Reinforced Concrete Pilesin Sand. // ARPN Journal of Engineering and Applied Sciences. 2, 4(2007), pp. 22-26.

[3] Lazovic, M.; Deretic Stojanovic, B.; Radovanovic, J. Sability of double elastically wedged CFT columns. $/ / 5^{\text {th }}$ 
Int. Congress of Serbian Society of Mechanics / Aranđelovac, 2015, pp. 1-10.

[4] Hibbitt, Karlsson \& Sorensen, Inc. ABAQUS standard user's manual version 6.12, 2012.

[5] Wang, S. T.; Isenhower, W. M. User's Manual for LPile, Version 2012-06, 2012.

[6] Sekulovic, M. Metod konacnih elemenata. Građevinska knjiga, Beograd, 1984.

[7] Moon, J.; Roeder, C.W.; Lehman, D. E.; Lee, H.E. Analytical Modeling of Bending of Circular ConcreteFilled Steel Tubes. // Engineering Structures. 42(2012), pp. 349-361. DOI: 10.1016/j.engstruct.2012.04.028

[8] Evrokod 4: EN 1994-1-1:2004. Proračun spregnutih konstrukcija od čelika i betona. // Beograd, februar 2006.

[9] Desayi, P.; Krishnan, S.; Saenz, L. P. Discussion of Equation for the Stress-Strain Curve of Concrete. // ACI J. 61(1964), pp. 1229-1235.

[10] Reese, L. C.; Van Impe, W. F. Single Piles and Pile Groups under Lateral Loading. // Balkema, Netherlands, 2007.

[11] Mosher, R. L.; Dawkins, W. P. Theoretical Manual for Pile Foundations. // Army Corps of Engineers, Washington, 2000.

[12] Evrokod 2: EN 1992-1-1:2004. Proračun betonskih konstrukcija, deo 1-1: opšta pravila i pravila za zgrade. // Beograd, februar 2006.

[13] Sapunar, N. Geotehnički elaborate - stambeno-poslovna građevina Cvjetni prolaz. // Institut građevinarstva Hrvatske d.o.o. zavod za geotehniku, Zagreb, 2007.

\section{Authors' addresses}

Marija Lazovic, MSc. civ. eng., Assistant

Faculty of Civil Engineering, University of Belgrade Bulevar kralja Aleksandra 73, 11000 Belgrade, Serbia

E-mail: mlazovic@grf.bg.ac.rs

Janko Radovanović, MSc. civ. eng.

Technical Director V.d.o.o. "Morava"

Ljubićska 8, 32102 Čačak, Serbia

E-mail: jankoradovanovic87@gmail.com

Biljana Deretic Stojanovic, PhD, civ. eng., Professor Faculty of Civil Engineering, University of Belgrade Bulevar kralja Aleksandra 73, 11000 Belgrade, Serbia E-mail: biljads@eunet.rs 